\title{
DISSOLVING THE DIVINE: THE TRAGEDY OF IDENTITY IN GENET'S "ELLE"
}

[...] derrière l'image, c'est le canto qui va se révéler puis se manifester (on se souviendra aussi du mot d'origine espagnole: canthus qui donne en français le mot chant mais qui désigne alors la face étroite d'un objet. L'emploi métaphorique de ce terme pourrait ainsi signifier le passage de l'image à la fonction incantatoire: la voie étroite de l'image).

—Jean-Paul Corsetti, "De l'image au chant: la voie étroite"

IN HIS RECENT BIOGRAPHY of Jean Genet, Edmund White tells of the dramatist's fascination with the Pope. Genet purportedly revealed to Laurent Boyer, his "exécuteur testamentaire" at Gallimard, that if ever the Pope invited him to the Vatican, he would accept in a second. The ecclesiastical pomp of the center of power of the Catholic Church intrigued him to no end (Jean Genet 497). For those who know anything of the life or works of France's celebrated "poète maudit," it probably comes as no surprise that Genet never did receive such an invitation. He did, however, indulge his fascination-and on his own terms. In the 1950s he wrote "Elle,"1 a one-act play that stages the complicated recitation of an autobiographical poem of and-at least at the outset - by the Pope.

In this posthumously published drama, a Photographer has been invited to take photographs of the Pontiff for mass distribution among Catholic believers worldwide. Despite the primary task of the Photographer-to photograph the Pope-he is first invited to hear the Pontiff's recitation of this poem in five Chants. Entitled "Les Sanglots du Pape," it traces the difficulties experienced in his becoming Pope: in Chant I how he moved from shepherd to head of the Catholic Church and how he became progressively isolated because of it; in Chant II what he had inside of him that permitted him to be chosen as the Pope; in Chant III how he sought for the means by which to best represent his image as Pope; in Chant IV how the image of the Pontiff exists for everyone in the world except himself; and, finally, in Chant $V$ how he attempted to rid himself of the image of Pope and return to his simple existence as shepherd.

But while the Pope has initially offered to recite this personal poem to the Photographer who has never heard it before, by the fourth Chant the Usherwho is also present-takes over its recitation. Surprisingly, by the end of the 
fifth Chant it is the Photographer himself who recites it. The Pope himself has long since left the stage. In her Lire le théâtre, Anne Ubersfeld notes: "Le personnage sur scène est parlé en principe par un seul comédien (et s'il y a des distortions, elles sont ressenties en tant que telles) [ . . . ]" (254). How are the "distortions" inherent in the shift in roles of the Photographer from audience of the Pope to performer for/of the Pope underlined in "Elle"? Are they anticipated within the Chants themselves? And can they be traced through the changing manipulation of words and structures in the announcements, endings, and (ex)changes of the five Chants of "Les Sanglots du Pape"?

\section{CHANTS OF LIMITS}

Because the Usher announces to the Photographer from the outset that the "Sanglots du Pape" is a sacred poem in five Chants (59), the division of the "Sanglots du Pape" into separate Chants-or parts of a poem-is never a mystery. Less clear to understand, however, is why the autobiographical ensemble is referred to as a poem and, moreover, why this poem is considered sacred. A poem is a work in verse, one of whose variants is traditionally the Chant. The fact that the body of the "Sanglots" is divided into Chants thus follows one of the accepted divisions of poems. But how is each Chant itself a work of poetry? Traditionally, but not necessarily associated with verse, poetry is importantly an act of language which aims to express or suggest through verbal combinations. Within this act of language, rhythm, harmony, and image are essential features. Having invited the Photographer, a self-described "chasseur d'images" (82), to capture the Papal image so that his traits and gestures can be consumed in printed form from Black Africa to the Touamatou Islands (24), in his five Chants the Pontiff undertakes to underline the importance of image by reciting the movement that started with his early fascination with image and ended with his adult deception by the role of Pope.

Besides the fact that as Pope, and within the framework of religious mythology, his words take on a sacred dimension, the adjective "sacred" is related to those things that can be qualified as having absolute value. The Pontiff himself articulates the absolute nature of his terrestrial power as head of the Vatican: "Mais Pape! Me voici Pape! J'avais atteint la définitive limite! Vers laquelle tendre, il n'en est plus?" (61). Each Chant in his sacred poem is either the recitation of the quest for or the self-distancing away from the absolute image.

However, rather than the five "set speeches" or "canticles" that Richard Webb calls them in his File on Genet (77), the Chants of the Pope's sacred poem are not "set" but unstable. The changing internal structures and the changing contents of the Chants themselves reinforce the notion of performative exchange in "Elle" and highlight the fusion of roles and identities for which the Pope's "Les Sanglots du Pape" provide both a means and a measure. 


\section{CHANT I}

The first Chant of "Les Sanglots du Pape" is by far the longest and certainly the most elaborate. In its first part the Pontiff charts his movement from shepherd to Pope and sketches the autobiographical details that lay the groundwork for his self-pitying poem:

J'avais 16 ans et j'étais berger. Nous passerons très vite sur une enfance toute d'effusions, de communion avec la nature, et les loups, avec les récits évangéliques que je plaçais au milieu de mes clairières et de mes draps. Enfin, je disciplinais cette ferveur éparse. Je connus l'étude, sa rigueur, son objet. Lentement—car du pâtre boiteux et bouclé en chandail au vieillard que vouvoient les archanges, il y a des trajets d'étoiles-lentement je gravis les échelons-espérons de la perfection-et ceux de la Hiérarchie. Météorique et lent, je fonçais dans le tas. Toujours dirigé vers une image avec laquelle je cherchais à m'identifier: diacre, curé, vicaire, évêque, cardinal (souriant) et d'autres, païennes et charmantes . . . Je fus élu par le Sacré Collège —et me voici. (60)

While punctuating his many steps towards the Papacy, the dashes used by the Pope in this introductory sequence also complicate his description of these steps. By breaking up while simultaneously fusing, by dividing as well as compounding his phrases, the Pope's targeted use of dashes by which to punctuate his recitation underlines his slow but persistent progression towards the Sacred College. His gradual climbing of the Vatican Hierarchy, his moving from Deacon to Priest to Vicar to Bishop, or beyond-from Bishop to Cardinal, and ultimately from Cardinal to Pope-is the result of a carefully channeled fervor inspired by his adolescence as shepherd in communion with nature and nourished on evangelical tales. By loggerheading the verb "to bore" with the process of hierarchical climbing that he is describing, the Pope sets up a clear juxtaposition of two separate and unparallel axes, or dimensions of movement. While the hierarchical movement might be described as an upward one, to bore into a pile of titles or images suggests a movement downwards or at the very least sideways through to a center. Rather than merely intersect in description, however, these apparently divergent stages of professional, spiritual, and personal development are symptomatic of a more profound process that is also occurring. The underlying process of breakdown that "effusions," "communion," "éparse," and "fonçais" describe reinforces the metonymic shift from Pope to sugarlumps that is underlined by the Usher's offering the Photographer "Papes" (for "sucres") to be dissolved in coffee both before the Pope's arrival on stage and again after the recitation of the final Chant-a process that can be described as the dissolving of the divine:

L'HUISSIER (tendant le sucrier): Un pape? Deux papes? (Il prend un morceau de sucre avec une pince à sucre et le tend au photographe) 
L'HUISSIER (tendant une tasse de café): Buvez. Ça vous remontera.

Un pape? Deux papes? $(20,82)$

This process of dissolution will furthermore be underlined by the fusion of titles, objects, and roles (Pope, shepherd, sugarlumps) evoked by the changing titles of the "Sanglots du Pape" ("Sanglots des morceaux de sucre," "Sanglots des petits bouts de sucre," "Sanglots d'un berger," and "Sanglots pastoraux").

After explaining that he always searched during his youth for additional images with which to identify, the Pope's retracing of his path to the Vatican in Chant I is notably interrupted-or punctuated-by a smile. Not only is this reaction at odds with what would appear as the gloomy process of self-revelation through the "Sanglots du Pape," but its occurrence after the Pontiff mentions the title of cardinal is also important. For besides the Pope, the Cardinal is the only member of the clergy present in the play. His entrances precede the entry of the Pope and follow the Pontiff's exit from the stage. Moreover, like the Pope, the Cardinal is incompletely clad. When stopped by the Usher on his way to a spot of early morning fishing, the Cardinal asks: "Vous voyez, je suis à peine vêtu [. . . .] Dites-moi, cela se voit, que je n'ai pas de soutane?" (37-8) Similarly, between the recitation of his first and second Chants, the Pope invites the Photographer to examine him from behind:

On m'a truqué. Et de plus en plus. Tenez, passez derrière moi. Regardez [....] Oui Monsieur, c'est bien cela. Derrière je montre mon cul. Inutile en effet d'user de l'étoffe pour le cacher puisqu'en principe on ne me voit jamais de dos. Donc si par hasard on regardait ce dos, ce cul nu, ce ne serait pas celui du Pape qu'on verrait, puisqu'il n'a pas de cul [. . . ] J'ai le cul à l'air-n'ayant pas de dos [. . . . ] (67-8)

Could the Pope's scandalous negligence in dress be modeled after the Cardinal's-only pushed several degrees further? Or is there even more to his identification with the Cardinal?

Cardinal is not only the title of a high official of the Vatican, but it also has sense as an adjective. That the Pope chooses to smile after listing "cardinal" as a source of inspiration in Chant $I$ is telling, for as an adjective "cardinal" means "of basic importance," something central, or critical to any system, construction, organization, or framework. The Pope having already explained that by becoming Pope he bore through to the center of the heap of images with which he sought to identify, its relevance in his quest for the ultimate image becomes clearer. But why the smile? Foreshadowing the thrust of his entire sacred poem, the Pope smiles ironically, because he knows that as Pope he has no center, that his is an office built entirely on image, one whose substance exists only through exchange. That the highest official models himself after an inferior therefore destabilizes or undermines the entire Hierarchical 
structure of the Vatican. For the Pope centers are asymptotic and his quest for and subsequent attempt to distance himself from the image of Pope an unending struggle.

To underline the infinity of this struggle, he pairs the preposition "vers" with "par" in the first sentence of the second paragraph of Chant I: "Je disais: dirigé vers une image: aimanté par elle." (60-1) Still further in the Chant "après" is linked to the prepositional chain initiated by "vers" and "par": "Amis, toute ma vie, je n'aurais couru qu'après cette image nouvelle qui se proposait et se refusait longtemps à mon désir" (61). In his self-modeling after images, in his self-direction towards, his attraction by, or his chasing after them, the Pope sets himself up in direct relationship to them. By becoming Pontiff_-"la définitive image"-_, by losing his "densité intérieure," he has reached a definitive limit:

Il me resterait donc à détruire cette image, dégringoler ces degrès, malgré ma sciatique, si péniblement grimpés et rejoindre le givre et les loups? [. . . .] Détruire l'image par le refus de la perpétuer — en moi, d'abord, de la reproduire hors de moi ensuite. (61)

Then by progressively dismantling the image that has become his center the Pope strives to destroy it and rejoin the frost and wolves that remain for him the cherished images of his adolescence. In his attempt to reject the "exigencies of Image," he harbors a desire to reclaim his youth as shepherd among the wolves by image duplication:

J'usai de ruses. Une fois, sur un cliché, je remplaçai mon pied par le pied d'un autre, puis ma jambe. Ensuite, ce fut la main d'un autre. Ici ce fut plus grave, car c'est un autre qui faisait avec moi le geste de bénir. Certes, c'était la main d'un prélat de Belgique, mais cela n'arrangeait pas les choses. Enfin, je ne prêtais que mon visage, puis, fatigué, et pensant que cela suffisait, juste une oreille de moi, puis les poils d'une oreille pour authentifier l'image. Enfin peu à peu je cessais de me faire représenter. Je disparus tout à fait. Je fus absent de toute représentation, cependant que les images du Pape se multipliaient à l'infini [ . . . ] (62)

The first Chant of the "Sanglots du Pape" finally dissolves into the Pope's recollection of the tears that followed the creation of his "abracadabrante personne." The steps that in the beginning of the Chant represent a means to an end are thus by the final paragraph cruelly converted into a stage for sorrow: "je m'asseyais sur une marche de l'escalier pontifical, et je pleurais en silence." (63).

\section{CHANT II}

By the time the Usher announces the Pope's second Chant, it is anticipated that the Pope will reveal the substance of his image to the Photographer. In 
reacting to his first Chant, the Photographer has acknowledged the Pope's sadness and has asked the Pope to reveal what existed inside him that permitted his becoming Pope. The Pontiff has promised to tell him:

PHOTOGRAPHE: [. . .] il fallait donc qu'il y eût en vous ce qu'il faut pour faire de vous cette image. Et cela, qu'était-ce donc?

PAPE: Je peux vous le dire. Cela durera le temps d'un second chant.

PHOTOGRAPHE: [. . .] vous n'êtes pas comme les autres, puisqu'on vous vénère $[. .$. . que se passe-t-il donc?

PAPE: Je vais vous le dire [ . . . ]

HUISSIER: [ . . . ] dites [. . .] pourquoi l'on vous vénère [. . . ]

PAPE: Je vais donc vous le dire [ . . . ] (64-6)

In keeping with his promise, the Pope turns towards Chant II after admitting to the Photographer that the rollerskates on which he is mounted ${ }^{2}$ give the illusion that he is carried by angels: "Le Souverain Pontife doit être porté par les anges. Il ne saurait marcher. Ainsi le veut l'Image. Il fallait donc un peu trafiquer l'homme. Je m'en tire assez bien, d'ailleurs. Mais je ne vous ai pas récité le Chant II. Les Sanglots du Pape? Vous n'y tenez pas? Le chant II est assez bref . . . " (68-9). But in the place of the Pope's second Chant the manuscript of "Elle" has a blank.

Can this blank in the manuscript be justified or explained? In his research on the interaction between a text and its reader Wolfgang Iser explains that communication in literature is a process that is regulated by the interaction between revelation and concealment: "[. . . gaps function as a kind of pivot on which the whole text-reader relationship revolves [. . . ] the structured blanks of the text stimulate the process of ideation to be performed by the reader on terms set by the text [. . . . Blanks leave open the connection between textual perspectives, and so spur the reader into coordinating these perspectives and patterns [. . . .]" ("Interaction" 111-12). Indeed, the stable pattern established in announcing the Chants of "Les Sanglots du Pape," which will be examined in detail in our second section ("Limits of Chants"), changes with respect to the references to the pivotal second Chant. Where Chant I is recited, Chant II will be said. Where Chant I is heard, Chant II will be listened to. "Entendre" is replaced with the more active verb "écouter" just as "réciter" is replaced at first with the less decorative "dire":

LE PHOTOGRAPHE: Il fallait donc qu'il y eût en vous ce qu'il faut pour faire de vous cette image. Et cela, qu'était-ce donc?

LE PAPE: Je peux vous le dire. Cela durera le temps d'un second chant $[\ldots]$ Je vais vous le dire $[\ldots]$ 
LE PHOTOGRAPHE: Je vous écoute. $(64,69)$

As opposed to the relatively passive act of hearing, listening implies a concentrated effort. Unlike recitation, which emphasizes the manner in which words are transmitted or delivered, saying merely makes reference to the process of verbal expression or pronouncement.

The shift before Chant II from the delicate balance between the verb "entendre" and the verb "réciter" to the implementation of a new system of transmission initiated by the use of the verb "écouter" and the verb "dire" reinforces a shift in the Pope's buildup to his second sacred Chant from the verb "pouvoir" to the verb "aller." This draws attention to the immediacy of his delivery: "Je peux vous le dire [ . . . ] Je vais vous le dire [ . . . ] Je vais donc vous le dire $[\ldots]$. . $(64,66)$. Not only is "pouvoir" changed to "aller," but the construction in the immediate future is repeated to emphasize that the Pope is, indeed, going to "say" in Chant II what makes him Papal. Moreover, Chant II is the only Chant of the sacred poem whose substance or content is announced or promised and thus anticipated before its actual delivery. Not only is its thematic content no secret, but it is referred to in reference to time: "Cela durera le temps d'un second Chant" (64). This combination of the temporal with the substantive can therefore only underline the importance of transformation as a process. Indeed, the entire sacred poem of the Pope is the process over time-and through the exchange and the transfer of substance-whereby identities fuse and images merge (like those and because of those of the Pope in Chant I) through performative exchange to infinity (the unlimited extent of time, space, or quantity). Anticipated as time, published as space, expected by the Photographer to be elaborated in terms of quantitative measures, and performed as silence, ${ }^{3}$ the absence of the substance of the second Chant of the Pope is therefore a condition of the text.

However, for Albert Dichy - who heads the Fonds Genet in Paris-as for subsequent critics of the play, it is due to the blank in the manuscript of "Elle" that Genet's first posthumously published play is unfinished, incomplete. Thus, in his Introduction to the first edition of the play Dichy theorizes:

On peut, certes, penser que dans l'éventualité d'une publication de son vivant, Genet aurait, ainsi qu'il le faisait habituellement, repris et développé la pièce et, sans doute celle-ci aurait-elle gagné en profondeur et gravité. ("Présentation" 12)

Dichy's reaction is understandable, for as Susan Suleiman points out in her Subversive Intent, to construct an unfinished story out of a fragmented text is a natural impulse of all readers who reduce the unfamiliar to the familiar or the unreadable to the readable (41). It is known, though, that to publish the text of "Elle" during Genet's lifetime was impossible, for the dramatist insisted that the play be published only after his death. Furthermore, Marc Bar- 
bezat, Genet's editor at L'Arbalète, confirms that the play was indeed considered complete by Genet: "Datée et signée, "Elle" était achevée" ("Barbezat" 87). If anything, the blank in the place of Chant II of "Les Sanglots du Pape" gives rise to what Iser describes as the "fundamental asymetry" between text and reader and makes possible the organization of a referential field of interacting textual elements which project themselves one upon the other $(109$, 114).

\section{CHANT III}

Having thus in Chant I reestablished or recalled the edifice of images that he had negotiated, and in Chant II extended this edifice beyond the bounds of representation-by actually representing emptiness or silence both textually and performatively - by his third Chant Genet's Pope is ready to move beyond self-representation. The Pope begins Chant III with a reconfirmation of what he has already established in his Chants as the truth of the Vatican economy of images: "J'établis donc que n'importe quel objet pouvait me représenter. Si n'importe quel visage, épaule, tempe, peuvent être le Pape n'importe quoi le sera tout entier" (71). Moreover, he quickly shifts in his use of the first person singular pronoun "je" to include the first person plural pronoun "nous." Whereas in the first Chant "je" and "nous" are also present, they operate differently in Chant III. Unlike their use in Chant III, in Chant I they are never used in the same sentence yet might refer to the same person.

J'avais 16 ans et j'étais berger. Nous passerons très vite sur une enfance toute d'effusions [. . . .] (60)

The "je" of Chant I refers to the Pope, whereas the "nous" could refer either to the Pope on his own-used thus as a grandiose, royal, or Papal "we"-or to the Pope and his auditors, the Usher and the Photographer. However, because he is sharing his tale with them, the "nous" in Chant I could also mean that as a group-Pope, Photographer, and Usher-they will soon have finished with the autobiographical preliminaries of his poem. In the third Chant the increasingly ambiguous use of "je" and "nous" within the same sentence as well as between sentences is symptomatic of a confusion of referents:

Je cherchai quel objet donnerait de nous et de notre auguste absence une idée juste. Je songeai d'abord à un dé à coudre, à une girafe en peluche, à une brosse à habit,-notre humilité ne le dédaignant pas-à ce mégot craché-oui, nous eûmes l'idée que dès qu'un mégot est foutu en l'air, il devient le Pape et a droit aux égards pontificaux. Nous allâmes plus loin, et jusqu'à cette idée que nous-mêmes, n'étant pas, c'est un rien qui nous représenterait le mieux [ . . . ] dans notre quête [. . . ] nous vint à l'esprit l'idée d'un objet de conservation courante-car les mégots, me 
disais-je entrent rarement en fraude chez les hommes honnêtes-me vint à l'esprit l'idée d'un bout de sucre. (72)

Not only does the Pope refer both to himself, the Usher, and the Photographer simultaneously and separately, but images become exchangeable objects. The ultimate image is suddenly interchangeable with the most banal, contemptible, and valueless of objects. Nothing, "un rien"-at the limits of identity-, would represent him/them the best-at the limits of quality.

Having explained how he dreamed up this system of representation by selfsubstitution, the Pope recounts how he issued a simultaneously "famous" and "secret" bull which established, regulated, and codified the representative power of sugarlumps:

Je lâchai une bulle célèbre et secrète établissant, réglant, codifiant les pouvoirs représentatifs du bout de sucre. Ainsi, dans tous les lieux du monde, et à chaque seconde, des millions de fidèles font de mon image une consommation invraisemblable. (72)

Besides the Pope's use of the present participle with "établissant," "réglant," and "codifiant" to highlight simultaneity or fusion of actions, as opposed to his continued use of the historical past as might be expected given his "Je lâchai," by using the present participle, the merged axes of time, space, and quantity that characterize (the absence of) Chant II are further extended. For all over the world and at every second, millions of believers consume the Pope's image. But this large scale consumption is further problematized by the very Papal bull that established its significance. To be simultaneously both famous and secret is not possible. However, besides the simultaneous and contradictory secrecy and celebrity of the Papal bull, its powers are representative. Photographs of the Pope-which previously might have served to transmit his sacred image worldwide - are replaced with shipments of sugar:

Au lieu de recevoir des kilos de photos d'un vieillard, les couvents, les presbytères, les bistrots, les casernes, les maisons de correction, les Parlements, les gares, les aérodromes, reçoivent des tonnes de bouts de sucre blanc, image idéale de Notre Candeur. On nous met dans une tasse de café chaud, de lait, de camomille, tchutt!! on a fondu. Un gosse, une vieille nous croque. Plus de Pape. (72-3)

Whereas in Chant I the infinite multiplication of the images of the Pope occurred in castles, thatched cottages, convents, churches, hospices, prisons, the brush, military barracks, and on farms ("des images du Pape se multipliaient à l'infini dans les châteaux, dans les chaumières, les couvents, les églises, les fermes, les hospices, les prisons, la brousse, les casernes . . ."), by Chant III only the convents and military barracks are evoked. As the sugarlumps dissolve in tea or hot coffee and the divine is dissolved so to speak, so 
too the distribution of the Pope's image diversifies: added to the list are "presbytères," "bistrots," "maisons de correction," "Parlements," "gares," and "aérodromes." Linking open space with airports, thatched cottages with Parliaments, and prisons with reform schools, sites of reception shift.

If, as the Pope recites in his third Chant, photographs are replaced by sugar, the official purpose of the Photographer's visit to the Vatican loses its relevance altogether. Without the need for photos of the Pope, official photographs no longer need be taken. Since the Photographer loses his role as image maker in the third Chant, by the final two Chants he is therefore free to take on a new role. It is, moreover, the Pope himself who initiates this shift in roles of the Photographer in the dialogue that immediately follows Chant III and that anticipates recitation of Chant IV. "Monsieur, monsieur, monsieur le photographe," the Pontiff therefore asks him, "vous qui êtes un homme, ditesmoi, est-ce que votre métier de chasseur d'images suffit à faire vivre votre petite famille?" "Les temps sont durs, monsieur," the Photographer admits in regret. As a consequence of his honesty, the Pope commands the Photographer "Laissez donc," and explains "le monde est plein de bouts de sucre." Most importantly, though, he immediately turns to testing the Photographer in the new role that by the end of Chant $\mathrm{V}$ the Photographer alone will perform:

Mais dites-moi, monsieur, dites-moi: J'avais 16 ans et j'étais berger . . .

Actively encouraging the Photographer's rereciting of the first Chant of his autobiographical poem, the Pope repeats the first sentence in its entirety. But he then transforms and interrupts his evocation of the remaining text. The life of shepherd in communion with the wolves and nature recalled in Chant $I$ is pushed yet further and transformed in Chant III. Wolves now drink from his hand, and his pockets overflow with cherries and locusts. Chant I's "enfance toute d'effusions, de communion avec la nature, et les loups" (60) is replaced with the more detail-specific "les loups buvaient dans ma main, mes poches regorgeaient de cerises et de sauterelles ..." (76) of the Pope's new version in Chant III. But how is the Photographer expected to be able to retell the Pope a version of "Les Sanglots du Pape" that he has never heard himself?

\section{CHANT IV}

This question is even more pressing after the Photographer encourages and anticipates the mounting (con)fusion of referents inherent in the Usher's performance of the fourth Chant and that follows the Pope's exit from the stage. The Usher has heard the Pope's "Sanglots du Pape" so many times before that he knows them by heart. The Photographer-for whom this is the first visit to the Vatican-has not only never met the Pope before but has never heard the Pontiff's sacred poem. To the Usher's "Voulez-vous les entendre?" the Photographer responds "Si cela ne vous ennuie pas? Et si vous les savez" (79). 
Standing in for the Pope and thereby acting the role of the Pope, the Usher (or
Usher-Pope) explains to the curious Photographer that whether it be as "[l']image sublime et pâle de la Miséricorde," "Tour penchée de l'Indulgence et du Pardon," "Verge flexible et douce vêtue de moire," "Aurore boréale sous le ciel d'Italie," "Majesté de Toutes les Majestés," "Acteur travesti," or "Chinois fatigué, travaillé dans le dur et le tendre," the Pope exists for everyone except himself. But the very image that he provides to the world and that is unavailable to him is destabilized by the shifting capitalization of the word "Pape," by the fusion of pronomial and verbal referents, and by the suspension of the Chant's conclusion:

[. . . . ] pour le monde entier le pape existe [ . . . ] pour le monde entier le pape existe, non pour moi. Chacun a le Pape. Le pape est pour chacun. Or moi qui le suis, je suis privé du Pape. (80)

Like the interchangeable use of "Chant" and "chant" in the announcements and conclusions of Chants that will be discussed in the next section, "Pape" and "pape" become interchangeable. Moreover, as it is not the Pope who is reciting this Chant, the specific referent of the "me" or "I" is difficult to pinpoint. Is the Usher simply representing the Pope's Chant verbatim? If he is, how can he justify suddenly failing to complete the Chant faithfully? How to explain his hasty "Monsieur, ne me demandez pas trop de détails, et acceptez ceci comme la fin du Chant IV des Sanglots pastoraux [. . . .]"? Is this how the Pope himself traditionally ends his fourth Chant? And is the Usher in his "[. . .] moi qui le suis, je suis privé du Pape [. . . ]" revealing a point of culmination in identity fusion: is he the Pope? Or is he merely admitting that he follows the Pope-whether it be in his capacity as Usher or through his present task of presenting the fourth Chant after the Pope has already recited the first three? Because both the verbs "être" and "suivre" share the first person present form "je suis," the real sense of this pivotal sentence of Chant IV remains ambiguous. To further underline the ambiguity of pronomial and verbal referents, the very last sentence of Chant IV, before the Usher-Pope asks the Photographer to settle for his apparently improvised ending, orchestrates the interplay between the tonic pronouns "him" and "me" and the verbs "to approach" and "to approve": "[. . . ] afin de pouvoir l'approcher . . . m'approuver $[\ldots . .]^{\prime}$ To approach the Pope is essentially to approve himself. Just as the Pope (or the Usher who performs for-by being or following-the Pope) is deprived of the image (or identity) of the Pope, so too by the end of the fourth Chant-as it might in the most perfectly constructed of French classical tragedies-the full crisis of identity is at its dénouement.

\section{CHANT V}

By the first sentence of the fifth Chant, the first person singular pronoun "je" refers simultaneously to "Pape," "Huissier," and "Photographe." Patrice 
Bougon acknowledges the importance of the changing referents of "I" in this sacred poem, but he emphasizes division and multiplication rather than the sharing or fusion that can also be traced:

Tres personajes en la escena se aproprian de una historia a través del uso del "yo," que poco a poco deja de tener sentido, ya no identifica a nadie. Si tomamos en cuenta su raíz etimológica encontramos que la palabra persona, en cuanto máscara de teatro, nunca descubrirá un identidad permanente. Para la escritura teatral de Genet, el "yo" se multiplica (o divida) ya que en un determinado momento el ujier y el fotógrafo pronuncian, al mismo tiempo un relato que debido a su género (la autobiografía) resulta confrontado a causa de los modos de enunciación que sufre. ("Lectura" 76)

The Usher begins the fifth Chant by interrupting the Photographer's attempt to explain his sympathy for the Pope's sense of deprivation. But he is immediately interrupted by the Photographer:

L'HUISSIER (l'interrompant): Et voici le Chant V des Sanglots du Pape: Enfin épuisé par tant d'efforts ...

LE PHOTOGRAPHE (l'interrompant à son tour): Je sais, je sais . . . tant d'efforts ...

The Photographer's earlier "Si vous les savez" (79) to the Usher-whereby he has urged him to continue with the recitation of Chants IV and V-is now replaced with the urgent need to show his own knowledge of the poem. The Photographer's first words therefore mark his definitive passage from passive listener to active participant in the recitation of the "Sanglots du Pape." Furthermore, they bridge the words of the Usher (or Usher-Pope) who continues ". . . pour me débarrasser de cette image ..." before both the Usher and the Photographer continue in unison: ". . qui maintenant ne pouvait plus être chassée par une autre, et puis, à l'extrême bord de la mort, sur le point de trépasser, enveloppé...." The Photographer's status as a performer of the poem now confirmed, this simultaneous recitation by the Photographer and the Usher yields to the Photographer's solo performance of the tragic conclusion of "Les Sanglots du Pape."

When the Usher begins the Chant, he is speaking both for and as Pope. Likewise, when the Usher is followed by the Photographer, the Photographer is speaking both as Photographer and Usher-filling-in-for-Pope. By the end of Chant V's first sentence, then, the Photographer is really Photographer speaking for Photographer-and-Usher-and-Usher-Usher-Photographer-Usher-filling-in-for-Pope. ${ }^{4}$ Each shift in performance of the Chant further complicates the notion of identity that is rehearsed through accumulation, fusion, and loss within the autobiographical poem. 
Moreover, the content of the final Chant pushes to an extreme what might be called the tragedy of identity that is the sacred poem of the Pope. While the fifth Chant represents the end or performative limit of the sacred poem itself, it also marks the limit of the image dissolution that has been underlined earlier by the metonymic shift from Pope to sugar. It stages the Pope's permanent loss through death of his pastoral identity, which is discovered through his inwardly directed retreat from image and the definitive breakdown of performance of his poem that it engenders.

The initial separation between reciter (Pope) and audience (Photographer) that existed at the beginning of Chant I has in this final Chant been completely broken down. The act of recitation becomes the conclusive action both in the exchange of and within the fifth Chant itself. Whereas in the first Chant the Photographer apparently hears the Pope's Chant for the first time, by the fifth Chant he interrupts the Usher, acknowledging that he already knows what comes next in the final account of the Pope's return within himself. He thus implies that he has, indeed, always already heard the entire sacred poem before:

HUISSIER: Enfin, épuisé par tant d'efforts ...

PHOTOGRAPHE: Je sais, je sais . . tant d'efforts ...

HUISSIER: . . p pour me débarrasser de cette image . . .

PHOTOGRAPHE ET HUISSIER: . . q qui maintenant ne pouvait plus être chassée par une autre, et puis, à l'extrême bord de la mort, sur le point de trépasser, enveloppé ...

PHOTOGRAPHE: . . . enveloppé par elle et risquant d'apparaître aux siècles futurs sous cette apparence irrémédiablement neigeuse et couverte de bijoux, je rentrai en moi-même et partis à la recherche du dénicheur amoureux du brouillard et des prunelles gelées. (81)

Pushed to the limits of image, the Pope (and now the Usher and the Photographer in their respective performative roles too) recounts in Chant $\mathrm{V}$ a withdrawal to his pastoral origins. Just as Chant I recounts the movement towards image, Chant $\mathrm{V}$ recounts the impossible return back from it to the stable center of carefree adolescence in the countryside. At the limits of image, risking self-suffocation under the jewels of the Vatican, the relatively simple jewels of nature-icicles on fruit in the winter fields, for example-seem much less threatening and more attractive to the Pope. But the quest for his original identity, his true self, or that which in him is really and intrinsically "he," the Pope's rejection of image, his rejection of the "she" which in his capacity as "sa sainteté" has, as Benveniste would remark, elevated him "au-dessus de la condition de personne et de la relation d'homme à homme" (Problèmes 231), and return to the solidity that was his life as shepherd, is a tragic one. He soon discovers his self long dead of sadness, hunger, and cold. 
Hélas, quand je l'eus rejoint, il était mort de tristesse, de faim et de froid. Je lui portai des couvertures, une bouillotte, du lait chaud, de l'aspirine: rien. Je le frictionnai: rien. Rien. Rien. Il était glacé. Je récitai la prière des Morts. (81-82)

The shared autobiographical poem thus ends with the startling self-discovery by the Pope of the frozen or solid body of the fused self that was. While the entire poem has orchestrated the gradual fusion or melting of the self ("he") into image ("she") and concurrent melting of the identities of Pope, Usher, and Photographer, it concludes, in this most performatively "fluid" of all the Chants, with the most frightening of images, that of the solid, unattainable, and forever lost. Recitation of the Chants themselves has given way to recitation as a mechanism within them. The "Sobs of the Pope" are the "[P]rayer of the Dead." Rather than the prayer of Death ("de la Mort") or to Death ("à la Mort") that one might anticipate here given the single body that is found, in his recitation of the prayer of the Dead ("des Morts"), the Photographer/Pope acknowledges a communal death. His recitation is their recitation, his prayer their prayer, his loss of self a common loss of self. In effect, his death is their death. Ultimately, then, the solid that stands in striking contrast to the fusion that operates within and through the Chants themselves is that of a common, final, and permanent certainty: that the regeneration of the self through the performance(s) of the Chants of "Elle" is also highly degenerative.

\section{LIMITS OF CHANTS}

The changing internal structures of these Chants which internally recount "limits" having been discussed, can the performative "limits" of these Chants that are inherent in their external structures shed further light on them? Can the changing ways in which characters announce, finish, react to, or evaluate the Chants of the Pope contextualize and reinforce the internal changes already discussed?

Before each of the Chants is recited, the Usher formally announces them. Yet after the departure of the Pope between Chant III and Chant IV, it is the Usher who both announces and begins delivery of the final two Chants of the Pope. This shifting in responsibilities and roles anticipates the more profound transformations at the semantic level of the sacred Chants themselves.

The way that the Pope initially announces the recitation of his first three Chants also changes:

PAPE: [. . . mais je veux vous réciter les Sanglots du Pape. Asseyezvous. (59)

PAPE: Mais je ne vous ai pas récité le Chant II. Les Sanglots du Pape? Vous n'y tenez pas? Le chant II est assez bref . . . 
PAPE: Mais il faut que je vous fasse entendre le chant III des Sanglots du Pape-ou encore le Chant des morceaux de sucre. (70-1)

After he leaves the stage, the Usher announces Chant IV and begins Chant V without a formal announcement:

HUISSIER: Mais, Monsieur, il a oublié le Chant IV des Sanglots du Pape, et le Chant V. Voulez-vous les entendre? (79)

\section{HUISSIER: (l'interrompant) (80)}

With the notable exception of Chant V, then, it is evident that both in the Pope's dialogue with the Usher and the Photographer before he leaves the stage and after the Pope's departure in the continuing dialogue between the Usher and the Photographer, the conjunction "mais" signals the shift in attention toward the Chants. As the Pope does in the three Chants that he presents before his hasty exit (Chants I, III, and arguably Chant II), the Usher starts his sentence with "mais" to indicate a move from the polite conversation that precedes them to the more formal presentations of Chant IV and Chant V. Whether he does so to follow the Pope's lead and thereby to help the Photographer better recognize the change in focus of their conversation is debatable. However, by the fifth and final Chant, which marks the point of total dissolution of the self in the play, "mais" completely disappears as initiatory marker, is replaced, instead, with the stage direction "l'interrompant," and yields to the veritable performative exchange of the fifth Chant.

Changes in the focus of conversation to each of the Pope's five Chants are initiated by "mais" and are immediately justified. They result from either desire, urgency, necessity, oversight, or forgetfulness. Thus to introduce his sacred poem, the Pope explains his wish to recite it. Immediately prior to his second Chant, the Pope remarks that he has yet to recite the second part of his poem and that to do so is important and pressing, whether or not the Usher wants to hear it and despite its brevity. Equally urgent, his third Chant must be shared with his auditors. Finally, after the Pope is no longer present on stage, similar justification to deliver the Pope's fourth and fifth Chants himself are given by the Usher. Because the Pontiff has evidently forgotten ${ }^{5}$ them, the Usher takes it upon himself to complete the sacred poem in five Chants by initiating recitation of Chant IV and Chant V for the Photographer.

In his formal announcements of the Pope's Chants, the Usher is less systematic than the Pope. Indeed, each time that the Pope alerts him that he is about to undertake the recitation of a Chant, the Usher in turn forewarns the Photographer, but his solemn warnings undergo transformations without maintaining the relative simplicity that is characteristic of the Pope's announcements. The Usher does not begin his announcements of the Chants to be recited by the Pope with "mais" or an equivalent initiatory marker but is 
consistent in his word order and use of the "futur proche" tense when announcing the three Chants that the Pope himself will actually recite. Rather than merely repeating the formulaic "Sa Sainteté va nous réciter [ . . .]" in announcing each Chant, the Usher chooses instead to vary his announcements. Thus he refers to "Sa Sainteté" as the "Le Souverain Pontife" before the Pope's recitation of Chant II: "Le Souverain Pontife va nous réciter [. . . .]" (69). But perhaps the most striking transformation in the Usher's announcements of the Chants of the Pope occurs between the third and final Chant actually recited by the Pope and the Usher's announcement of the now departed Pope's fourth and fifth Chants. "Réciter" (Chants I-III) suddenly yields to "entendre" (Chants IV-V). It thereby signals a shift in the delivery or transmission of the final two Chants.

As with the Pope's announcements of his desire, the urgency, or the necessity to share his first three Chants with the Photographer, this verbal shift from "réciter" to "entendre" in the Usher's announcements will also play a role in the reception of the Chants by the Photographer. The verb "entendre" is always used in the infinitive and thereby escapes particular notice. However, in the announcements of Chants, the transformation of the verb "réciter" from the infinitive to the past participle "récité" and to the historic past form "récitai" in the Photographer's delivery of the final portion of the fifth Chant draws attention to it. Indeed, recitation and its changing forms between the Chants is a crucial feature of the Pope's sacred poem: it is both a means of information exchange and an essential communicative strategy in "Elle."

Why does the Pope transmit the Chants of his sacred poem in such a way? One of the meanings of to recite is to "say" without "sincerity." By reciting these Chants which are to reveal the truth about himself, by formulaically manipulating delivery of his autobiographical poem, the Pope succeeds in altogether avoiding to do that which he has promised. His choice of recitation as a delivery style, his saying without sincerity or veracity completely undermines from the outset his enterprise of sincere or truthful self-revelation. Moreover, in the movement from the verb "réciter" to the verb "entendre," from reciting to being heard, there is a distinct shift in emphasis from source of formal delivery to site of reception. Put another way, the act of recitation emphasizes formal activity with attention paid to the origin and the manner of delivery, whereas the act of hearing - as opposed to that of listening-is decidedly more passive.

The semantic differences that complement the shift in communication from source to recipient of recitation between the first and fifth Chants further complicate the system of poetic self exchange staged in "Elle." Recitation is the act of saying aloud that which one knows by heart or memory. The conditions that foster it are useful in explaining the hasty exit of the Pope between the deliveries of Chant III and Chant IV. If, after having recited his first three Chants, the Pope did indeed forget his fourth and fifth Chants-as suggested 
by the Usher's "Mais, Monsieur, il a oublié le Chant IV des Sanglots du Pape, et le Chant V" (79)-to escape from the stage would certainly appear the simplest way for him to avoid showing his forgetfulness.

By far the most interesting consequence of the change in verbs from "réciter" to "entendre" in the announcements of the Pope's Chants by the Usher is the corresponding change that occurs at the level of performer in the play. In French the "partie récitante" of a poem is that part or sequence of a text chanted by a single voice. Once the Pope exits the stage and thus leaves his Chants to be delivered by the Usher, and because the first three Chants of "Les Sanglots du Pape" have been recited by the Pontiff alone, it is impossible for the Usher to announce in good faith the recitation of the Pope's fourth and fifth Chants. The change from single to multiple voices is still further emphasized by the Photographer's participation in the delivery of the fifth and final Chant. This complicated performative fusion occurs between Chant IV and Chant V: Chant IV is delivered by the Usher (standing in for the Pope who has left the stage) and Chant V delivered respectively by the Usher, the Photographer, the Usher, the Usher and the Photographer, and the Photographer (all standing in for the Pope and, simultaneously, for each other). All of this can be explained by a single shift in the mode of delivery of the Chants. Having dropped the promise of a recited Chant or a verbal sequence delivered by a single voice, the Usher announces and anticipates the shift to multiple voices or the changing dynamics of performance that is initiated in Chant IV and carried through to its euphonic but nonetheless troubling limit in Chant V.

Besides the lack of the initiatory marker "mais," the shift that occurs between the various forms of the verb "réciter" and the infinitive of the verb "entendre," and the significance that these differences have within the unstable means of information transmission in the Pope's sacred poem, several additional transformations occur between the Usher's announcements of Chants. Moreover, they render the delineation of the boundaries of the announcements, or announcing sequences, of Chants increasingly difficult to determine. The most obvious differences between the Usher's announcements of the Pope's Chants is in his own manner of delivery of these announcements themselves. According to the stage directions of "Elle" when the Usher announces Chant I, Chant II, and Chant III of the Pontiff's sacred poem he is solemn:

L'HUISSIER (solennel): Ecoutez. Sa Sainteté va nous réciter les Sanglots du Pape. Poème sacré en cinq chants. Chant I.

L'HUISSIER (solennel): Le Souverain Pontife va nous réciter le chant II des Sanglots du Pape. (Au Pape). En marche!

L'HUISSIER (solennel): Sa Sainteté va nous réciter le Chant III des Sanglots du Pape, intitulé encore chant des petits bouts de sucre! (59, $69,71)$ 
Symptomatic of the increasingly complicated system of exchange that occurs after the Pope's departure from the stage, in the continuing representation of the five Chants of the Pope by the Usher and the Photographer, the Usher's style of delivery of the verbal sequences that announce Chant IV and Chant V is comparatively nondescript:

L'HUISSIER: Chant IV des Sanglots du Pape [ . . . ]

L'HUISSIER (interrompant [le Photographe]): Et voici le Chant V des Sanglots du Pape $[\ldots](79,80)$

As the characters lose their identities in their fusion with one another, so too delivery style simultaneously loses its distinctive character.

Even at the less conspicuous level of punctuation, the Usher's announcements of the Chants of the Pope change dramatically between Chants I-III and Chants IV-V. While his announcements of the first three Chants are clearly separated from the Pope's Chants by a period or exclamation mark ("Chant I."; "En marche!"; "[ . .] chant des petits bouts de sucre!") and by a shift in voice (Usher to Pope), beyond the third Chant and after the Pope's departure, the period is replaced by a colon: "Chant IV des Sanglot du Pape: car il y avait pire hélas à tout ce que nous avons dit [ . . . Et voici le Chant V des Sanglots du Pape: Enfin, épuisé par tant d'efforts . . . " $(79,80)$. Thus there is no longer a separation in roles between the announcer and the performer of the Chants. Beginning with Chant IV, then, the colon is the only punctuational device employed to signal the shift from announcement to performance of the Chants by the Usher.

The sequences that formally end Chants further reinforce the transformations in the verbal sequences that announce Chants by and/or of the Pope and that anticipate the complexity of the transformations revealed and operating within the Chants themselves. The endings of the Chants, like the announcements of the Pope's Chants either by the Pope himself or by the Usher, vary in style and structure. Just as all Chants are formally announced, Chant I, Chant III, and Chant V all end with sentences that begin with "Fin." Yet Chants II and IV altogether lack formal endings. Chant II cannot have a formal ending, because it is left blank in the manuscript. But unlike Chant II, whose very absence in the text precludes a formal ending, Chant IV does exist in the manuscript, and its ending is decidedly ambiguous. The Usher leaves open the possibility that the real-if not rehearsed-ending of the fourth Chant might differ from the ending that he provides after the Pope's untimely departure by ending it with a double imperative. Equally plausible is the possibility that Chant IV might be distinctive by virtue of lacking an ending. This could justify the Usher's telling the Photographer to settle for an improvised ending: "Monsieur, ne me demandez pas trop de détails, et acceptez ceci comme la fin du chant IV des Sangots pastoraux" (80). But the Usher's 
ambiguous use of "ceci" further complicates matters, for it is unclear whether he intends for the Photographer to accept the actual sentence that he is in the process of pronouncing as the "ending" to Chant IV or whether he is referring, instead, to the sentence that directly precedes it. In other words, does "ceci" refer in the sentence "Et c'est afin de pouvoir l'approcher . . . m'approuver [ . . . ]" (80) to the points of suspension at the beginning of the sentence or to the sentence in which it is an element? Compared to the ambiguity of the ending of Chant IV and the absence of the ending (and content) of Chant II, the use of the terminal marker "Fin" in the relatively stable endings of Chant I, Chant III, and Chant $\mathrm{V}$ most closely parallels the uses of the initiatory marker "mais" in the beginning sequences of the Chants: "Fin du chant I [ . . . ] Fin du Chant III des Sanglots du Pape [... . ] Fin du Chant V des Sanglots d'un berger" (63, 73, 82).

Besides the differences in style and structure between the endings of the Chants of "Les Sanglots du Pape," the endings furthermore differ in efficiency when compared to those sequences that announce Chants. Overall, the process of ending Chants in "Elle" is faster and lacks some of the ritual baggage associated with their announcements. To announce Chants, both the Pope and the Usher are involved: the Pope warns the Usher that he is about to recite a Chant; the Usher then in turn warns the Photographer. However, following the Pope's ending of Chants I, II, and III, the Usher is not obliged to reiterate to the Photographer that the respective Chants have indeed been completed.

To further underline the process of metamorphosis highlighed by the Pope in his poem and the dissolution of identity that is initiated between characters as a result of their presentations and exchange of it, changes in capitalization and titles occur within and between the announcements and endings of its Chants. The inconsistency in the capitalization of the very word Chant by the Pope, the Usher, and the Photographer thus poses problems of interpretation both at the textual and performative levels. How to "interpret" the fluctuation between the use of Chant and chant, both of which refer to the units of the Pope's sacred poem? According to Bruno Bayen who first directed "Elle," although these changes in capitalization were noticed by the cast during the early rehearsals of the play, no effort was made to "stage" them (Personal interview).

The variation in the capitalization of the seventeen references to Chant within the play thus underlines at a very simple level the instability of the universe of images that for Genet is exemplified by the pageant and pomp that is the Vatican. Furthermore, the dynamics of exchange that operates between the six small letters and the eleven capital letters in Genet's spellings of the constituent Chants of the Pope's sacred poem reflects more complicated changes occurring within the title of the poem itself. Referred to initially by the solemn Usher as "Les Sanglots du Pape," by Chant III the Pope's sacred poem in five 
Chants begins to undergo noticeable transformation. Unlike the changes in capitalization between "Chant" and "chant," which might best be perceived only when reading the play, changes in the title of the Pope's sacred poem are, by contrast, easier to remark both at the textual and performative levels of the drama and are, in such a way, important transformations that are also meaningful when seeing or hearing it performed on stage. References in announcements and endings of specific Chants to their collective title, "Les Sanglots du Pape," also change just as in the Usher's announcements of Chants his references to the Pope vary between "Sa Sainteté" and "Le Souverain Pontife." However, more than the single transformation that occurs with reference to the Pope himself ("Sa Sainteté" to "Le Souverain Pontife"), there are a total of four changes of varying degree in the transformations of the title of the Pope's sacred poem: "Sanglots du Pape" (Chant II); "Sanglots du Pape," "morceaux de sucre," "petits bouts de sucre" (Chant III); "Sanglots du Pape," "Sanglots pastoraux" (Chant IV); "Sanglots du Pape," "Sanglots d'un berger" (Chant V). Whereas in the change from "Sanglots du Pape" to "Sanglots d'un berger" a single noun substitution occurs ("berger" for "Pape"), in the move from "Sanglots du Pape" or "Sanglots d'un berger" to "Sanglots pastoraux," there is an additional transformation from noun to adjective. Even more striking is the radical jump from "Sanglots" to "morceaux" or "petits bouts de sucre." Furthermore, these transformations do not occur in the order listed above. "Pape" does not gradually move from noun to adjectival form. Adjectives neither disappear in the order described into the sugarlumps nor reemerge in different form as the little pieces of sugar suggested in the titles. By the end of the exchange of the Pope's sacred poem in five Chants, the Pontiff has, nonetheless, both disappeared and undergone a radical metamorphosis. The changing titles of Chants thus become the vehicle for the the dissolving of the divine, the movement from Pope (as sacred or "sacré") through sugarlump form (as sweet or "sucré") back to shepherd, his original role in life. The Pontiff recalls and, through titular dissolution, rejoins his origins.

As further evidence of the protean nature of the poem's system of performative exchange, the reactions and evaluations by the Pope, the Usher, and the Photographer, which follow the recitation of the Pope's five Chants, are varied too. Measurable or noticeable physical reaction to the Chants by the Pope occurs only following Chant I, Chant II, and Chant III. First, the Usher responds to the initial Chant by wiping away tears with a handkerchief. Similarly, the Photographer cries following the second-missing or absentChant. Yet unlike the Usher before him, the Photographer makes no effort to wipe away his tears. Finally, by the end of the Pope's third Chant, the Photographer only alludes to a physical reaction when he tells the Pope that he has had tears in his eyes on more than one occasion over the course of the recitation. While varying both in degree and stage of emotional reaction, all three responses involve tears which are referred to after the recitation of Chants by 
the Pope. Interestingly, the Pope does not react emotionally to his own Chants themselves. His only reference to tears occurs within the title of the sacred poem or "Sanglots du Pape." He does, however, shed tears between his recitation of Chant II and Chant III when acknowledging the difficulty of his plight: "Oh là, là! Oh que c'est difficile. (Il pleure)" (70).

Besides these emotional reactions that are linked either directly or indirectly to tears and that follow the first three Chants, every Chant also elicits a verbal reaction or evaluation of some kind. The verbal reaction of the Usher upon hearing the first Chant of the Pope is one of evaluation: fate, he concludes, is atrocious and terrible. In so evaluating the Pope's first Chant, the Usher provides a model for the Photographer to follow, for the Photographer will in turn subsequently react (but in varying degrees) to Chants II, III, and IV. Although it is the Photographer himself who completes the fifth Chant of the Pope, it is the Usher who provides the verbal encouragement that follows. In his reaction to the Pope's second Chant, the Usher provides encouragement through opposition. As opposed to what the Pontiff may have pronounced about the artificiality of his power in the body of his second Chant, his power over the Sacred College is real. Moreover, the Photographer points out that the effects of the Pope's personal or very human presence in the world are also real: "[. . .] votre pouvoir sur le Sacré Collège est réel. Vous avez une action personnelle sur le monde" (69). Likewise, in his continued sympathy for the Pope, the Photographer explains to him that of all people he above all understands, or relates to, the pain that the Pope describes in Chant III better than anyone.

In keeping with the changes that parallel the gradual fusion of identities occurring at all levels of the play, by the fourth Chant of the Pope the measurable physical reaction of tears following the Pope's recitations of Chants I-III disappears and gives way instead to the long silence that follows Chant V. Not only does the Photographer's verbal reaction to the fourth Chant reveal his understanding and pity for the Pope's solitude, but it exposes his own inner suffering as a consequence of hearing it. By the fourth Chant, then, reactions and evaluations by the Photographer have become interiorized and as a result are more substantial or personal. Pushed further still, by the end of the Photographer's exhausting and acrobatic delivery of the Pope's fifth Chantwhich confirms his definitive move from audience to participant and ultimately solo performer-he is urged by the Usher to drink something to help him recover from it.

But for the Photographer-just as for the Pope whose fifth Chant rehearses an impossible return to his origins-to fully recover and to become once again what he was before listening to and ultimately performing (in) "Les Sanglots du Pape" is impossible. His shifts in role from Photographer for the Pope to audience of the Pope's sacred poem and ultimately to performer for/of the Pope as orchestrated through the complicated recitation of the poem antic- 
ipate his replacement altogether as officially invited Photographer at the Vatican: ${ }^{6}$

(Entre un photographe semblable au premier).

LE 2e PHOTOGRAPHE: Eh bien, je suis là, comme convenu.

L'HUISSIER: Mais qui vous a dit d'entrer?

LE ler PHOTOGRAPHE (timide et gêné): Ne lui dites pas d'insultes, je vous en prie, c'est moi ...

L'HUISSIER: Je vois bien qu'il vous ressemble, mais ça ne peut pas être vous, puisque vous êtes là, et lui, là.

LE ler PHOTOGRAPHE (toujours timidement): C'est mon photographe officiel, monsieur. C'est lui qui était chargé de fixer la scène inoubliable, d'en conserver l'image ... (82-83)

With its distortions of character, the Pope's sacred poem in five Chants is ultimately a pretext for one final distortion. The fusion and confusion of referents that is staged within and by the complicated recitation of "Les Sanglots du Pape" is finally and definitively underlined by the penultimate shift in the stage for performances and for which Genet's Vatican provides the "self"indulgent context.

\section{New York University}

1. "Elle" was first performed at the Festival de Parme on 26 April 1989 and was revived at the Thêatre de Gennevilliers in a mise en scène by Bruno Bayen from 28 September to 31 October 1991. As Emile Benveniste explains in his Essais de linguistique générale, "Il (ou elle) peut servir de forme d'allocution vis-à-vis de quelqu'un qui est présent quand on veut le soustraire à la sphère personnelle du "tu" ("vous") [.... en manière de révérence [....]" (231) This use of the third person singular pronoun is evident in the title of the play. For the sake of clarity, however, "sa sainteté" will be referred to in the masculine throughout this article. Likewise, we translate the French "chant" as Chant and the French "Huissier" as Usher.

2. The Pope arrives on stage on rollerskates and is pulled from side to side by a cord-clearly visible to the public. Just as this play explores the mechanisms of climbing the Hierarchy of the Vatican, it similarly shows-at the very physical level-the machinery behind the Pope's public appearances. Bayen chose not to respect the stage direction necessitating a cord for, he believes, it would have been inavoidable not to think immediately of the Pozzo and Lucky couple in Samuel Beckett's En attendant Godot-something that he did not want in his production of the play. (Personal interview)

3. In the first performance of "Elle" in Paris, actress Maria Casarès, who played the Pope, gesticulated awkwardly during the period that she was to have recited Chant II (Bayen).

4. In observing how the Photographer becomes the subject of enunciation of the fifth Chant, Patrice Bougon concludes that the identity of the characters is "uncertain" and that the entire play is thus "troubling" ("Pièce" 87).

5. It is difficult to determine whether the Pope forgot to recite these final two Chants before exiting because he had to leave in such haste or whether he actually forgot the Chants and, as a consequence, was forced to make his exit. Both possibilities are plausible, but both are prob- 
lematic. For if it were so important to recite his sacred poem, why would the Pope leave before having completed it? If - as the Usher's reactions to the Pope's recitation of the second Chant suggest-the Pope regularly recited this poem and created a ritual of such habitual recitation to invited guests, how could such a well-rehearsed action suddenly and unexpectedly result in forgetfulness, or in his drawing a blank?

6. The Usher's original role as gatekeeper is also undermined.

\section{WORKS CITED}

Bayen, Bruno. Personal interview. 7 January 1994.

Benveniste, Emile. Problèmes de linguistique générale. Vol. 1. Paris: Gallimard, 1966.

Bougon, Patrice. "Genet: une pièce posthume." Magazine littéraire 265 (1989): 87.

"Une lectura de Ella." Jean Genet camino de santidad: Ella una obra inedita. El Publico 41 cuadernos. 72-8.

Dichy, Albert. Présentation. "Elle." By Jean Genet. Décines: L'Arbalète, 1989. 9-14.

Genet, Jean. "Elle." Décines: L'Arbalète, 1989.

Iser, Wolfgang. "Interaction between Text and Reader." The Reader in the Text: Essays on Audience and Interpretation. Ed. Susan R. Suleiman \& Inge Crosman. Princeton: Princeton UP, 1980. 106-119.

Suleiman, Susan. Subversive Intent: Gender, Politics, and the Avant-Garde. Cambridge, MA: Harvard UP, 1990.

Ubersfeld, Anne. Lire le théâtre. Paris: Scandéditions/Editions sociales, 1993.

Webb, Richard C. File on Genet. London: Methuen Drama, 1992.

White, Edmund. Jean Genet. Trans. Philippe Delamare. Paris: Gallimard, 1993. 
Copyright of Symposium is the property of Heldref Publications. The copyright in an individual article may be maintained by the author in certain cases. Content may not be copied or emailed to multiple sites or posted to a listserv without the copyright holder's express written permission. However, users may print, download, or email articles for individual use. 